\title{
REFLEXÕES SOBRE A ORGANIZAÇÃO PÚBLICA MUNICIPAL DO TURISMO DE IRATI-PR, SOB ENFOQUE DAS CATEGORIAS ANALÍTICAS GEOGRÁFICAS: LUGAR E PAISAGEM
}

\author{
Maycon Luiz Tchmolo ${ }^{1}$ \\ Patrícia Denkewicz ${ }^{2}$ \\ Nicolas Floriani ${ }^{3}$
}

Resumo: A presente pesquisa traz como conceitos centrais a serem discutidos e relacionados: planejamento turístico, políticas públicas de turismo, lugar e paisagem. A partir destes conceitos, confronta-se com a pesquisa empírica realizada no município de Irati-PR. Assim sendo, traçou-se os seguintes objetivos: analisar o projeto de planejamento turístico para as paisagens da sede de Irati e distritos circunvizinhos; apresentar os lugares e/ou paisagens onde a população iratiense realiza suas práticas sociais, de modo, a demonstrar sua ligação com o turismo; e, analisar se dentro do planejamento turístico as ações fomentam mudanças ao espaço, lugar ou paisagem. Os métodos da pesquisa permearam em uma entrevista com os responsáveis pela organização pública do turismo em Irati; e registro fotográfico das paisagens compreendidas como turísticas por estes. Como resultados, percebeu-se que ainda há muito que se fazer e investigar para um desenvolvimento harmônico da atividade.

Palavras-chave: Políticas públicas; planejamento turístico; práticas sociais; Irati-Pr.

\section{Reflections on public municipal organization of tourism Irati-PR, in analytical approach of geographical categories: place and landscape}

\begin{abstract}
The research brings presents as central concepts to be discussed and related to: tourism planning, public policy, tourism, place and landscape. From these concepts, confronted with empirical research conducted in the city of Irati-PR. Thus, drew up the following objectives: to analyze the project planning to tour the sights of the headquarters of Irati and surrounding districts; present the places and / or landscapes where people iratiense performs its social practices, so, to demonstrate their connection with tourism; and analyze within tourism planning actions to foster change space, place or landscape. Research methods permeated in an interview with the public organization responsible for tourism in Irati, and photographic record of the landscapes and tourist understood by them. As a result, it was realized that there is still much to be done to investigate and harmonious development of the activity.
\end{abstract}

Keywords: Public policy; tourism planning; social practices; Irati-Pr.

\section{INTRODUÇÃO}

A importância do turismo no desenvolvimento econômico de base local, demonstra um lado da situação de como se encontra a atividade nos dias atuais, em que o turismo pode ser uma

\footnotetext{
${ }^{1}$ Mestre em Gestão do Território (UEPG). Bacharel em Turismo (Unicentro). Professor Colaborador do curso de Turismo da Unicentro. Email: mayconlt@hotmail.com

2 Especialista em Mídias na Educação(UNICENTRO). Bacharel em Turismo (Unicentro). Estudante. E-mail: patriciadenkwicz@hotmail.com

${ }^{3}$ Doutor em Meio Ambiente e Desenvolvimento (UFPR). Mestre em Ciências do Solo (UFPR). Engenheiro Agrônomo (UFPR). Professor Adjunto da Universidade Estadual de Ponta Grossa (UEPG).E-mail: nicolas@uepg.br
} 
alternativa para pessoas que despossuem de formas de geração de renda. Todavia, existem ações que fazem que o turismo modifique espaços e paisagens, perfazendo, desta maneira, que locais marcados e dotados de simbolismo sejam transformados para as finalidades que a atividade turística deseja.

Em alguns locais a atividade já é consolidada como um dos principais (se não o principal) pilares da economia. Não obstante, dificilmente será renegado, devido sua imposição no espaço, ou seja, esses locais, fundamentalmente, tem por finalidade a visitação de outros povos, pois, por algum motivo, de ordem política, religiosa ou mercantil foram demarcados para essa utilidade. Consequentemente, muitos indivíduos possuem como único meio de sobrevivência e de captação de renda os benefícios econômicos advindos do turismo, logo a mudança de ocupação traria a essas pessoas o receio e a incerteza da exploração de outra atividade.

Deste modo, o turismo é relevante e primordial para esses locais. Contudo, a grande maioria dos municípios brasileiros, e porque não do mundo, não necessariamente sobrevivem da atividade turística, possuindo outras formas de arrecadação de divisas. Esses lugares possuem seus atrativos turísticos, contudo, as políticas públicas não são voltadas eminentemente para o fomento do turismo ou, então, não haja iniciativas que visem essa finalidade. Isso é o que acontece no município de Irati, objeto de estudo dessa pesquisa. Para que a atividade turística desenvolva-se adequadamente se faz necessário um planejamento e políticas públicas, pois a atividade pode trazer efeitos negativos irreversíveis para a localidade.

Barretto et al. (2003) diz que as políticas públicas no turismo teria como função desenvolver harmonicamente essa atividade, no sentindo de relacionar Estado, superestrutura jurídico administrativa e iniciativa privada, tendo em vista beneficiar toda sociedade. Teoricamente isso deve ser bem visível, entretanto, na pratica, é um exercício que dificilmente se enxerga, principalmente, quando se trata de municípios que buscam de alguma forma tirar proveito do turismo. No entanto, a falta de políticas públicas do turismo em uma localidade encadeia problemas dos mais diversos níveis, pois não há planejamento capaz de harmonizar todos os envolvidos na atividade turística.

Acerca disso, a presente pesquisa traz como conceitos centrais a serem discutidos e relacionados: planejamento turístico, políticas públicas de turismo, lugar e paisagem. Aproxima-se, portanto, juntamente a pesquisa empírica as bases teóricas da ciência geográfica que, para tanto, apresenta-se como base epistemológica deste estudo, e 
possibilitou o apoio teórico e metodológico durante todo o processo investigativo. $E$, como objetivos, se tem: analisar o projeto de planejamento turístico para as paisagens da sede de Irati e distritos circunvizinhos; apresentar os lugares e/ou paisagens onde à população iratiense realiza suas práticas sociais, de modo, a demonstrar sua ligação com o turismo; e, analisar se dentro do planejamento turístico as ações fomentam mudanças ao espaço, lugar ou paisagem.

A necessidade da aproximação entre Turismo e Geografia, tem-se ao fato que as análises do turismo foram caminhando a passos lentos, a partir de resultados de pesquisas, mas que ainda não permitiram formar um corpo teórico (BOULLÓN, 2002).

Destaca-se a paisagem, primeiramente, pelos escassos estudos existentes no campo turístico. Yázigi (2002, p. 11) ressalta que: "hoje, todavia, pelo menos no Brasil, sentimos necessidade de muitas outras reflexões, que estão pouco presente na bibliografia sobre a relação da paisagem com o turismo". Num segundo momento, estudar os aspectos paisagísticos de um município denota a compreensão da relação entre sujeito-coletividadesnatureza, ou seja, notar a interação entre um indivíduo ou grupo de indivíduos perante seus patrimônios paisagísticos municipais. A paisagem é um símbolo que pode deixar uma pessoa disposta ou desanimada no seu dia-a-dia (BOLSON, 2004).

Deste modo, a população local é o principal usuário da paisagem inserida em sua localidade, ora defende-se o seguinte pensamento:

\begin{abstract}
Entretanto, uma clara advertência desde o começo: ao defender a preservação da paisagem lato sensu - natural e urbana - penso mormente em sua importância para o habitante do lugar, de que é tributária e só depois, no turista. Descarto assim, o caráter do voyerismo que o mundo inteiro tenta imprimir ao turismo. É que para o residente do lugar, a paisagem e o espaço são virtualmente conclamados a desempenhar várias funções, entre as quais: o de lugar mediador para a vida e as coisas acontecer - não como receptáculo, mas sujeito a permanente transformação; a de referências múltiplas: geográficas, psicológicas (lúdicas, afetivas), informativas; a de fonte de contemplação que, como a arte, pode significar um contraponto ao consumo; a de fonte de inspiração e, sobretudo, a de alimento à memória social, através de todas as suas marcas (YÁZIGI, 2003, p. 69).
\end{abstract}

Lugar, no sentido de pertencimento de um povo a um local específico, no qual estes desenvolvem suas atividades corriqueiras, tendo em vista aspectos como sua sobrevivência e suas múltiplas relações com os seres humanos (LISBOA, 2004). Assim, a relação local-global é um fenômeno social que enseja o problema do turismo de massa e do turismo desenvolvido localmente sem apelo mercadológico, mas que emerge das práticas cotidianas 
da população local que conota na paisagem valores tradicionais e, ou afetivos, transformando-o em lugares de lazer e sociabilidade.

No entanto, para alcançar esse resultado se faz necessário o planejamento buscando reduzir os efeitos negativos ao meio ambiente, moradores ou aos atrativos turísticos. 0 planejamento no turismo aparece como uma das principais ferramentas para o desenvolvimento da localidade, tanto para atender as necessidades dos turistas como as dos moradores da localidade.

Boiteux (2002) considera o planejamento como instrumento para transformações, que o planejamento tem como objetivo de pensar em providências que serão tomadas para fazer de um local um grande destino turístico. Os atrativos turísticos precisam de um bom planejamento, pois quando bem organizado poderá definir a volta do turista, a satisfação da comunidade local e imagem do atrativo.

\section{METODOLOGIA}

Para se auferir os objetivos da presente pesquisa, foram adotados procedimentos metodológicos, a partir de técnicas e práticas, as quais permearam na aplicação de uma entrevista com os responsáveis pelo planejamento do turismo em Irati; e registro fotográfico das paisagens compreendidas como turísticas pelo órgão governamental responsável pelo turismo do município. Para isso optou-se pela abordagem qualitativa.

O roteiro de entrevista semiestruturada com o Sr. Rafael Ruteski, Secretário de Patrimônio Histórico, Turismo, Cultura, Lazer e Desportos, juntamente com a Sra. Samanta Regina dos Santos, Chefe do Departamento de Turismo de Irati, consta com 9 (nove) questões, 1 (uma) no intuito de compreender a formação dos mesmos e as outras 8 (oito) procurando compreender quais as ações e práticas adotadas por esse órgão municipal para o desenvolvimento do turismo na cidade de Irati. Tal entrevista foi aplicada no mês de agosto de 2011. O registro fotográfico das paisagens e lugares das práticas sociais cotidianas foi realizado no início do mês de fevereiro de 2012.

Diante dos dados coletados na pesquisa empírica, relacionou-se com a ciência geográfica que para tanto, apresenta-se como base epistemológica deste estudo, e possibilitou o apoio teórico e metodológico durante todo processo investigativo. 


\section{DISCUSSÃO TEÓRICA}

\section{Políticas públicas, planejamento turístico e práticas sociais: revê recorte}

O crescimento do turismo traz a necessidade de elaborar políticas públicas que sejam aplicáveis ás localidades que buscam desenvolver tal atividade, aproveitando seus potenciais turísticos juntamente com a participação ativa da comunidade local e órgãos governamentais.

Com base em Teixeira (2002, p. 2) entende-se por políticas públicas as "[...] diretrizes, princípios norteadores de ação do poder público; regras e procedimentos para as relações entre poder público e sociedade, mediações entre atores da sociedade e do Estado." Ou seja, ações planejadas e fomentadas pelo governo que tem por finalidade atingir beneficamente uma coletividade e harmonizar a relação entre poder público e sociedade. Para Perret (2007) as políticas públicas são o conjunto de dispositivos de ações, implantadas em consequência das decisões de uma ou várias autoridades públicas no intuito de alcançar um objetivo ou de atingir uma finalidade ligada ao interesse geral é que deve ser mantido para garantir o desenvolvimento das comunidades.

Barretto et al. (2003) diz que as políticas públicas no turismo teria como função desenvolver harmonicamente essa atividade, no sentido de relacionar Estado, superestrutura jurídicoadministrativa e iniciativa privada, tendo em vista beneficiar toda a sociedade. Teoricamente isso pode ser bem visível, entretanto, na prática, é um exercício que dificilmente se enxerga, principalmente, quando se trata de municípios que buscam de alguma forma tirar proveito do turismo.

Os mesmos autores ainda expõem

Se o espaço é ocupado de forma indevida, é porque faltaram políticas públicas adequadas na área da construção civil, faltou um plano-diretor ou faltaram fiscalização dos órgãos do Estado e meios para cumprir leis. Se os empreendimentos turísticos estão contaminando, poluindo rios e mares, prejudicando o meio ambiente natural, é por falta de políticas públicas na área ambiental, fundamentalmente por falta de rede de esgoto e tratamento de afluentes. Se o turismo gera subempregos, é porque falta uma política trabalhista adequada (BARRETTO et al., 2003, p. 35).

A falta de políticas públicas do turismo em uma localidade encadeia problemas dos mais diversos níveis, pois não há um planejamento capaz de harmonizar todos os envolvidos na atividade turística. Quando trata-se aqui sobre a atividade socioeconômica do turismo, não envolve somente aqueles que diretamente se beneficiam do turismo (empreendedores e 
subordinados da hotelaria, de empresas de alimentação, de empresas de transporte, de agências de viagem e o governo), mas, alguns órgãos que indiretamente se relacionam com a atividade como, por exemplo, os serviços de saúde e de segurança, bem como toda a população local que, prioritariamente, deve ser tratada como alicerce de todo esse processo.

Castro (2004, p. 09) diz que compete ás políticas públicas estabelecer diretrizes orientadas através do planejamento de estratégias, identificando necessidades e problemas nos mais variados segmentos. No entanto essas politicas públicas devem ser avaliadas e monitoradas depois de aplicadas, segundo Hall (2001, p.31) essa avaliação e monitoramento são fundamentais na medida em que

- avaliam o grau de necessidade de políticas e intervenções do governo; possibilitam o teste de hipótese referente ao funcionamento do processo, a natureza dos resultados e a eficiência dos programas; especificam sobre resultados e impactos da política; medem a eficiência e relação custobeneficio das políticas e planos de turismo em termo de recursos financeiros, humanos e de capital.

Contudo, o que se percebe é a preocupação de órgãos governamentais e iniciativa privada em proporcionar ao turista uma estada, na qual ele supra suas necessidades e supere suas expectativas em relação ao local visitado. Confirma-se essa afirmação, principalmente, em bibliografias relacionadas com o marketing e administração do turismo. Beni (1997) diz que o vendedor (organismos públicos e privados) deve estimular os desejos e as necessidades dos compradores (turistas) em todo o processo ocorrente. Deste modo, as ações mercadológicas do turismo têm por finalidade satisfazer o turista, pois esse que depositará o dinheiro no local visitado.

Assim sendo, por um lado o planejamento do turismo municipal, diante de suas ações, mormente, capitalistas, possui vertentes que fortalecem o desenvolvimento econômico, em congruência à geração de renda per capita e familiar; por outro ele destrói entornos e transforma paisagens e lugares, dotados de subjetivismo no imaginário social, em espaços para circulação e recepção do turista em prol de seus investidores e empreendedores.

É importante que a comunidade local e os órgãos governamentais tenham o conhecimento de que planejar é se desenvolver de forma organizada, tendo em vista a situação real e a situação que se pretende alcançar e de como alcança-la. A autora Ruschmann (1997, p 47), afirma que o planejamento é uma atividade que envolve a intenção de estabelecer 
condições favoráveis para alcançar os objetivos almejados. Tem por fim o fornecimento de facilidades e serviços para que uma comunidade atenda seus desejos e necessidades.

Não há como se planejar um lugar, mas sim o espaço e a paisagem. E o planejamento é exercício constante daquelas localidades que desejam se desenvolver economicamente com o turismo. Assim sendo, enfocando sobre planejamento estratégico em um município, Llona et al. (2003) diz que há possibilidades de transformação econômica, social e política, ora essa operacionalização gera um consenso entre os múltiplos atores participantes, na busca de um futuro desejável. Tratando-se de planejamento turístico municipal Ruschmann e Widmer (2000, p. 67) entendem que é o

processo que tem como finalidade ordenar as ações humanas sobre uma localidade turística, bem como direcionar a construção de equipamentos e facilidades, de forma adequada, evitando efeitos negativos nos recursos que possam destruir ou afetar sua atratividade.

Assim, o planejamento é uma iniciativa imprescindível para qualquer localidade que deseja criar melhorias, organizar ações, desenvolver-se social e economicamente, minimizar erros, entre outras vantagens, que fazem com que o planejar seja fundamental para o desenvolvimento de um município. A autora Ruschamann (1997) ainda complementa dizendo que o planejamento é uma importante ferramenta, que ajuda a evitar danos ambientais e a manter a atratividade dos atrativos naturais e culturais. Assim ajudando a continuação da atividade turística com pouca degradação do meio.

Contudo, o planejamento deve ir além da preocupação com o turista, pois como afirma Fridgen (1990) o desejo e as preferências da comunidade local devem ser consideradas, pois o planejamento deve resultar na melhoria da vida da comunidade local, tendo em vista que turismo baseia-se fortemente no bem estar dos autóctones.

No entanto, as práticas sociais são entendidas como as relações entre indivíduos, em meio a eles e a comunidade, entre determinados grupos ou ainda entre esses grupos e sociedade. Envolve-se nas práticas sociais uma diversificação cultural, ou seja, se relacionam diferentes classes sociais, etnias, opções sexuais. (GARCIA-MONTRONE et al., 2004).

Ocorrem casos em que o fluxo da atividade turística invade e se relaciona com as práticas sociais cotidianas. É importante destacar que nessa ocorrência deve haver um apreço do turismo com essas práticas sociais. O Código de Ética Mundial para o Turismo (2000, p. 4), através do seu artigo 1으 (Contribuição do turismo para o entendimento e respeito mútuo entre homens e a sociedade) enfatiza a seriedade de se considerar as práticas sociais 
A compreensão e a promoção dos valores éticos comuns da humanidade, em um espírito de tolerância e respeito à diversidade, às crenças religiosas, filosóficas e morais são, por sua vez, o fundamento e a conseqüência de um turismo responsável. Os agentes do desenvolvimento turístico e os próprios turistas deverão prestar atenção às tradições e práticas sociais e culturais de todos os povos, incluindo as minorias nacionais e as populações autóctones, e reconhecerão suas riquezas (CÓDIGO DE ÉTICA MUNDIAL PARA O TURISMO, 2000, p. 4).

Diante essas considerações, entende-se que a partir das operacionalizações dentro de um planejamento turístico, deve se levar em conta que o ator principal de quaisquer ações fomentadas é o morador local. Do mesmo modo, a sociedade tem papel principal e fundamental na elaboração das políticas públicas para o turismo, pois, anteriormente de qualquer prática turística, ela que usará cotidianamente as infraestruturas e atrativos turísticos.

\section{Irati-PR: caracterização e atrativos}

De acordo com o censo do IBGE (2010) Irati possui uma população de 56.207 habitantes, distribuídos em uma unidade territorial de 999,519 km², e com uma densidade demográfica de 56,23 habitantes por $\mathrm{km}^{2}$. Desses habitantes, 44.932 pessoas residem na área urbana $(79,94 \%)$ e 11.275 na área rural (20,06\%). Os moradores do sexo feminino representam $50,7 \%$ da população (28.499 mulheres) e a masculina 49,3\% (27.708 homens).

Irati ainda possui traços marcantes de uma cidade interiorana e colonizada por europeus. Apesar do crescimento quantitativo da indústria, podendo mencionar empresas multinacionais que se instalaram no município como, por exemplo, a Yazaki Autoparts do Brasil Ltda. (Japão) e a Iracome Brasil (França), a agropecuária e, principalmente, o comércio (serviços) se sobressaem e são os principais indicadores socioeconômicos do município. Com base no Produto Interno Bruto (PIB) do município, dados do IBGE (2008), o comércio é o precursor da economia local com 63,83\% do valor adicionado, seguido da agropecuária com $19,94 \%$ e da indústria com $16,23 \%$.

Quanto aos atrativos turísticos no município de Irati cingem à algumas reflexões se exatamente são pontos turísticos ou podem ser entendidos como espaços determinados para uma determinada prática social. Embora essa incerteza, apresenta-se, por meio de documentos consultados da Prefeitura Municipal de Irati, lugares e paisagens que são entendidos pelos órgãos governamentais como atrativos turísticos. 


\section{$\checkmark$ Imagem de Nossa Senhora das Graças}

Esse monumento pode ser considerado o único atrativo localizado na área central da cidade. Por ter status da maior imagem de Nossa Senhora das Graças do mundo (figura 1), com 22 metros de altura, atrai indivíduos interessados pelo turismo religioso. Também, atrai muitos moradores que veem a estátua como uma protetora da cidade, por meio da sua fé religiosa. A prática religiosa é o que mais se percebe no local. O espaço conta também com um centro de informações turísticas, onde são vendidos produtos produzidos por artesãos locais, com um mirante que se avista todo o centro e alguns bairros da cidade e com um playground.

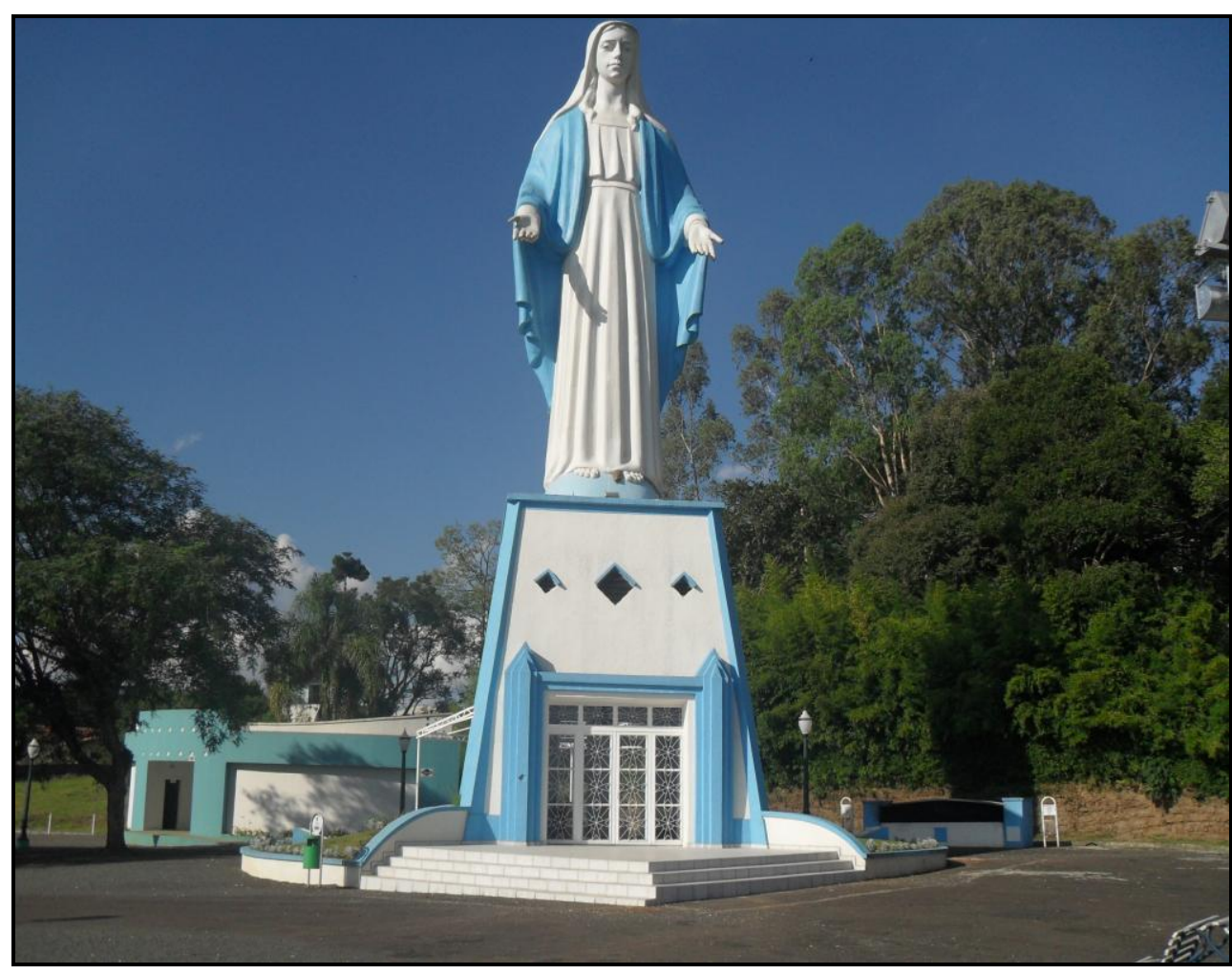

Figura 1: Imagem de Nossa Senhora das Graças Fonte: TCHMOLO (2012)

\section{$\checkmark$ Parque Aquático e de Exposições Santa Terezinha}

Quando perguntado a muitos habitantes, quais são os pontos turísticos de Irati? A maioria responde que é a Santa (Imagem de Nossa Senhora das Graças) e o Parque Aquático. Contudo, essa visão parte da própria organização municipal do turismo, pois eles exploram o Parque Aquático como uma área de visitação turística, que evidentemente não é. 
O Parque Aquático é um ponto de práticas sociais, onde parte da população iratiense exerce atividades físicas, bem como serve para um local de passeio familiar, lazer e entretenimento. Este espaço (figura 2), localizado no Bairro Rio Bonito, possui área de $79 \mathrm{mil} \mathrm{m}^{2}$ e consta com: lago, um pavilhão de exposição, com 1.017,5 m², uma mini-estação ferroviária, canchas de areia para prática esportiva, pista de cooper e ciclismo, pedalinhos, academia ao ar livre para adeptos e playground.

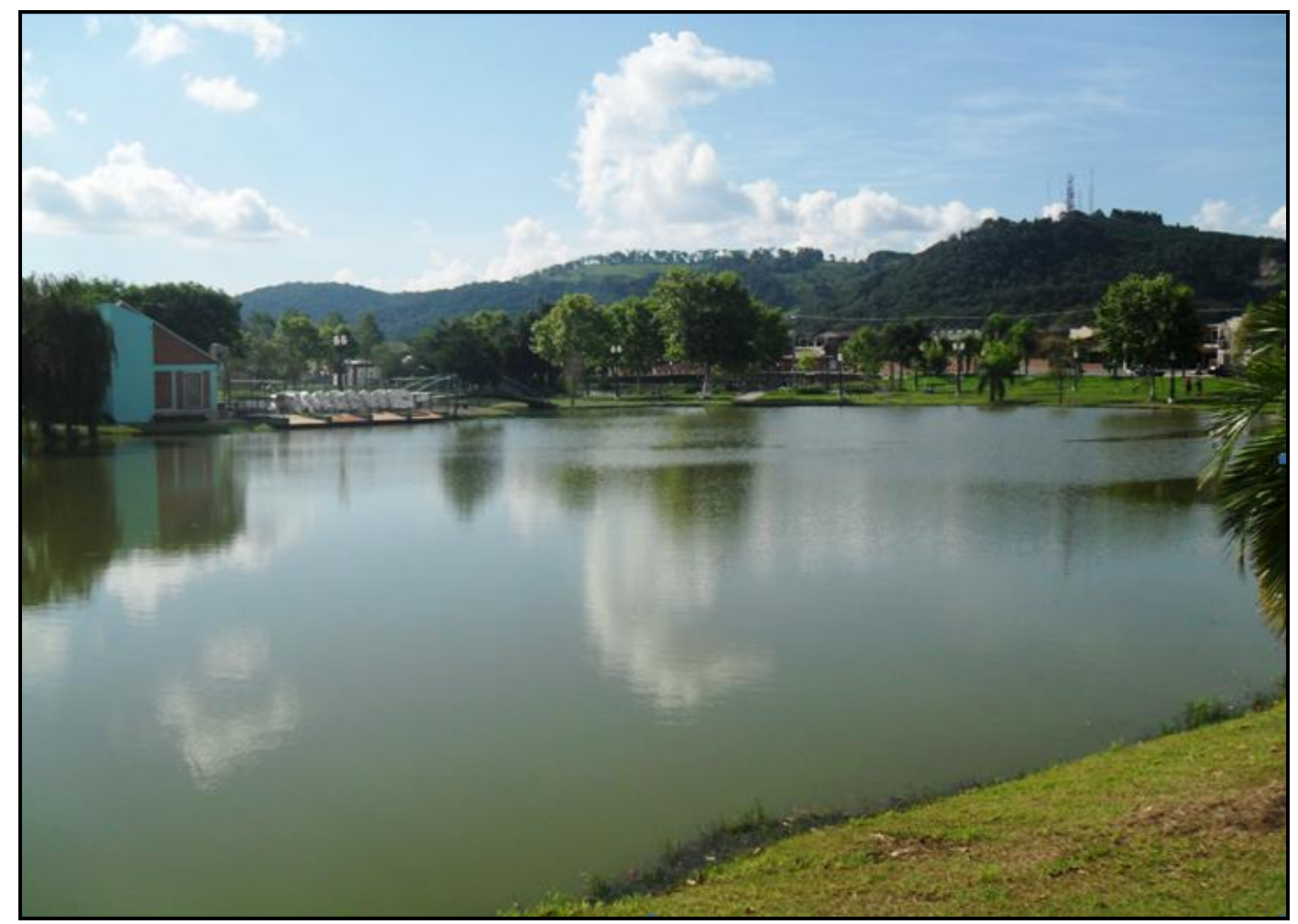

Figura 2: Vista parcial do Parque Aquático Fonte: TCHMOLO (2012).

\section{$\checkmark$ Cachoeiras}

As cachoeiras são espaços turísticos potenciais e relevantes dentro do município, contudo não são exploradas pelo turismo. Esses locais recebem mais habitantes da própria cidade que se deslocam para tais em busca de descanso, principalmente, nos finais de semana.

A única cachoeira localizada próximo ao centro da sede municipal é denominada Recanto Rubens Dallegrave (Figura 3). As outras cachoeiras divulgadas para o turismo no município são: Cachoeira do Itapará, a $45 \mathrm{~km}$ da cidade (figura 4); Cachoeira do Cadeadinho, a $36 \mathrm{~km}$ da cidade (figura 5); Cachoeira do Faxinal dos Antônios, a 44 km da sede municipal (figura 6); e Cachoeira do Teodózio Hlatki, a 45 km da cidade (figura 7). 


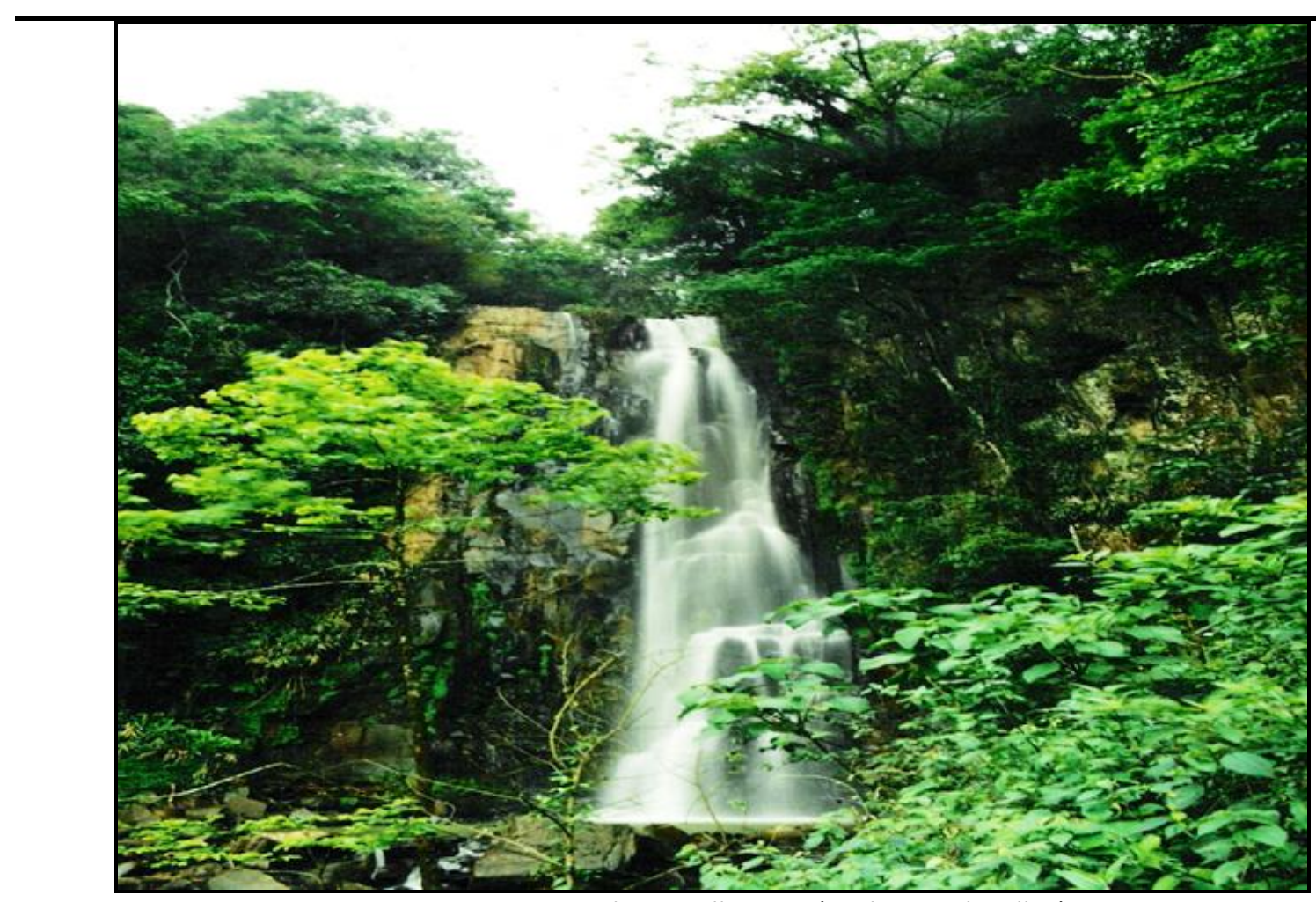

Figura 3: Recanto Rubens Dallegrave (Cachoeira do Fillus)

Fonte: PMI (2010)

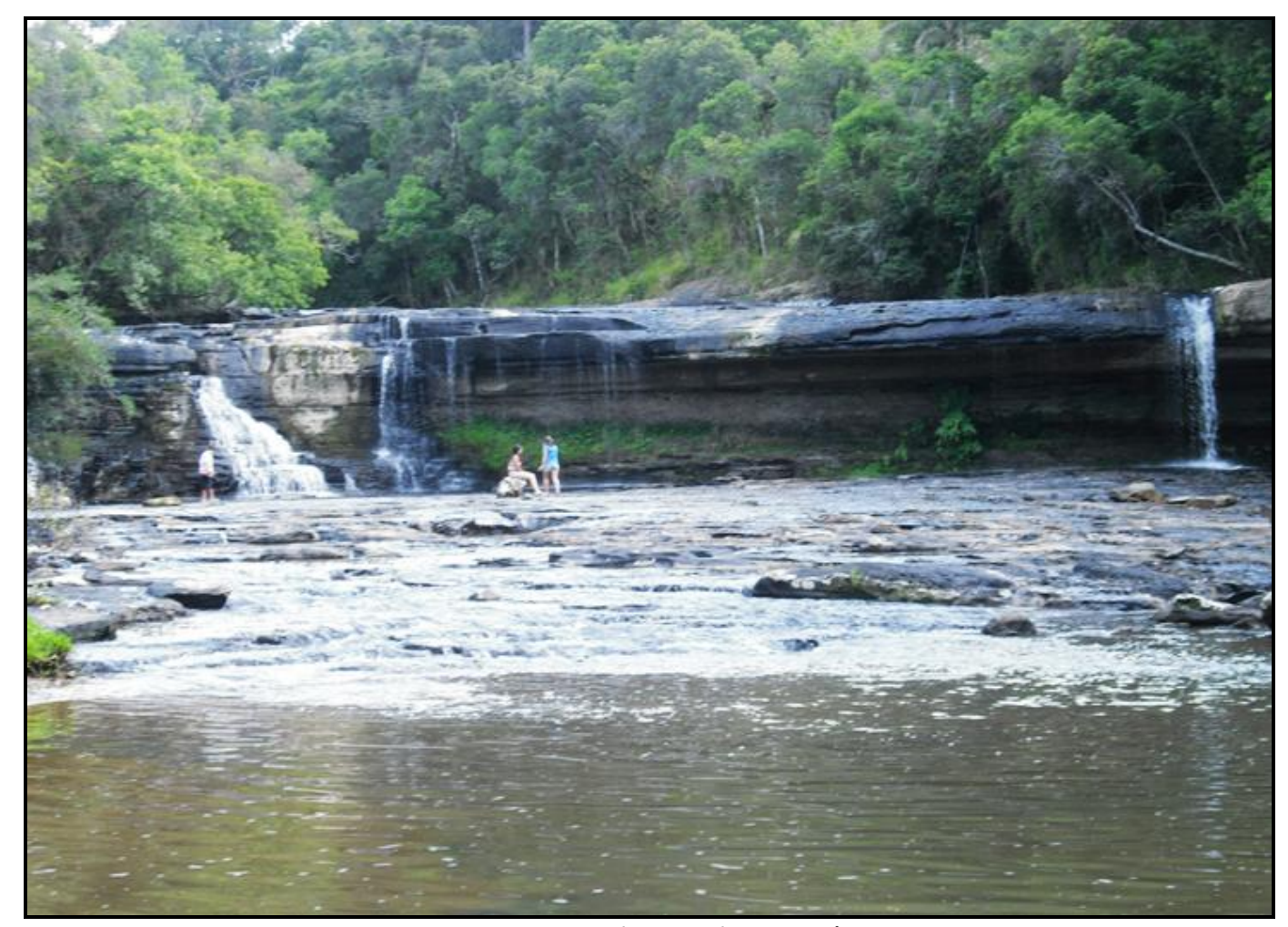

Figura 4: Cachoeira do Itapará

Fonte: TCHMOLO (2012) 


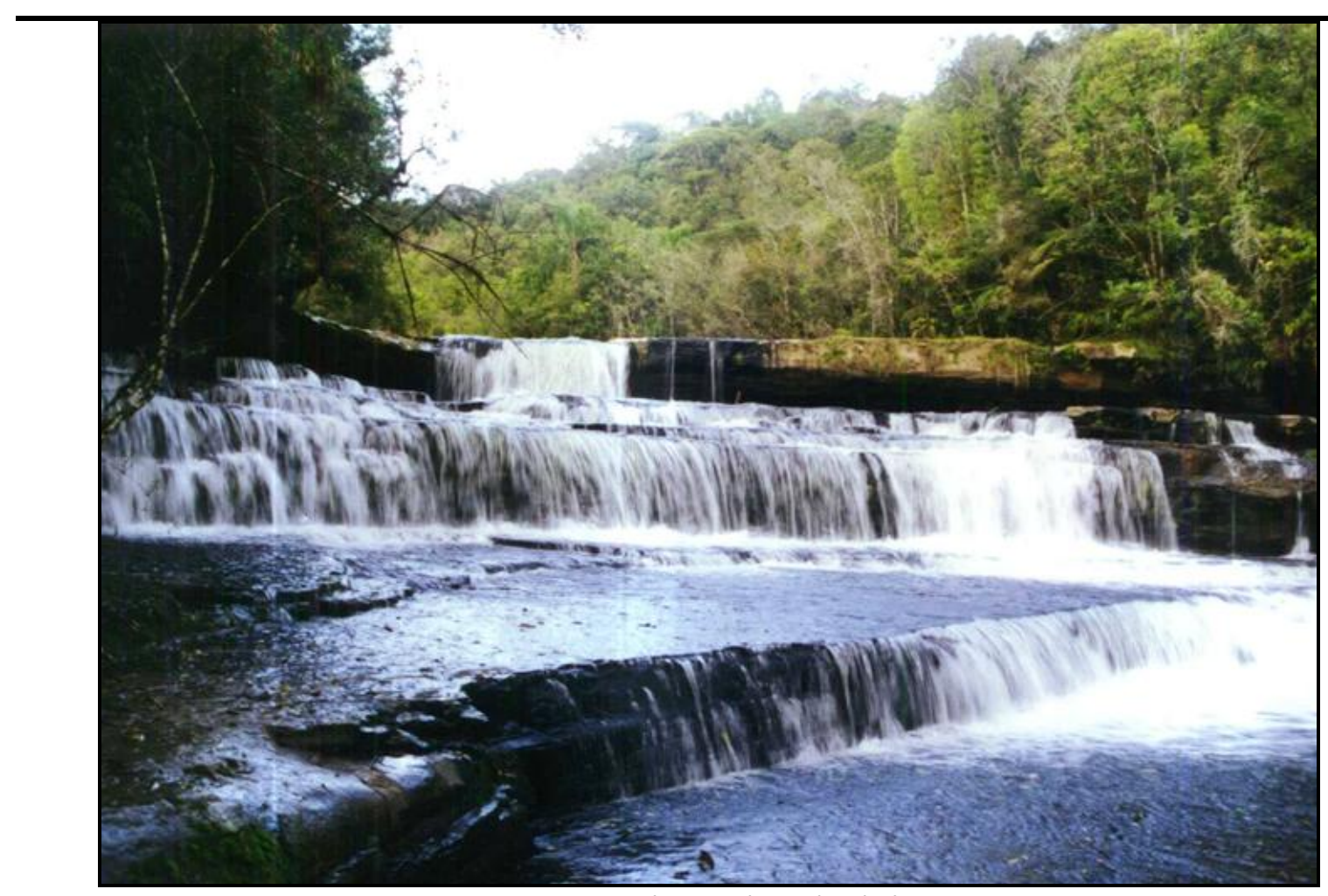

Figura 5: Cachoeira do Cadeadinho Fonte: PMI (2010)

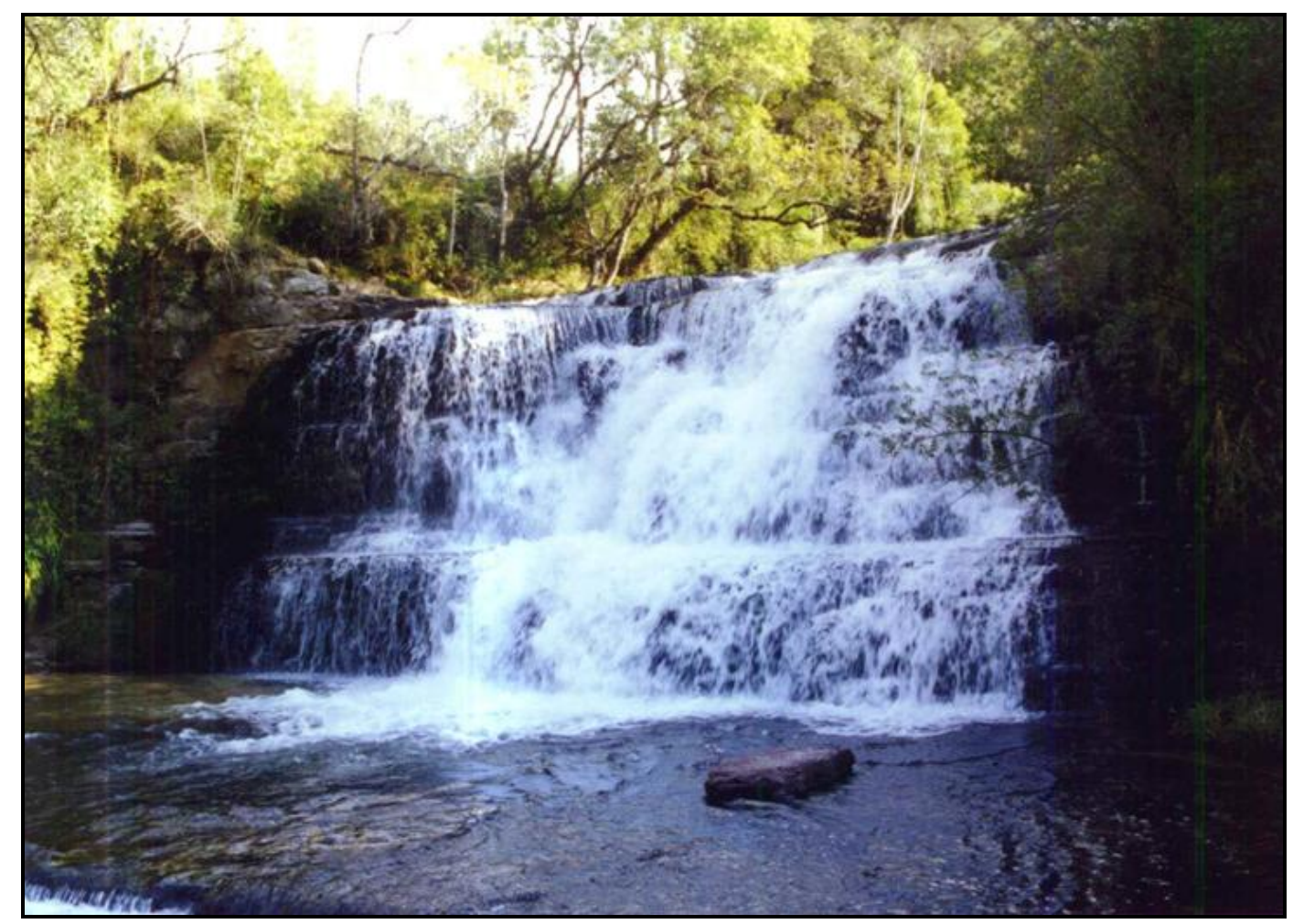

Figura 6: Cachoeira do Faxinal dos Antônios Fonte: PMI (2010) 


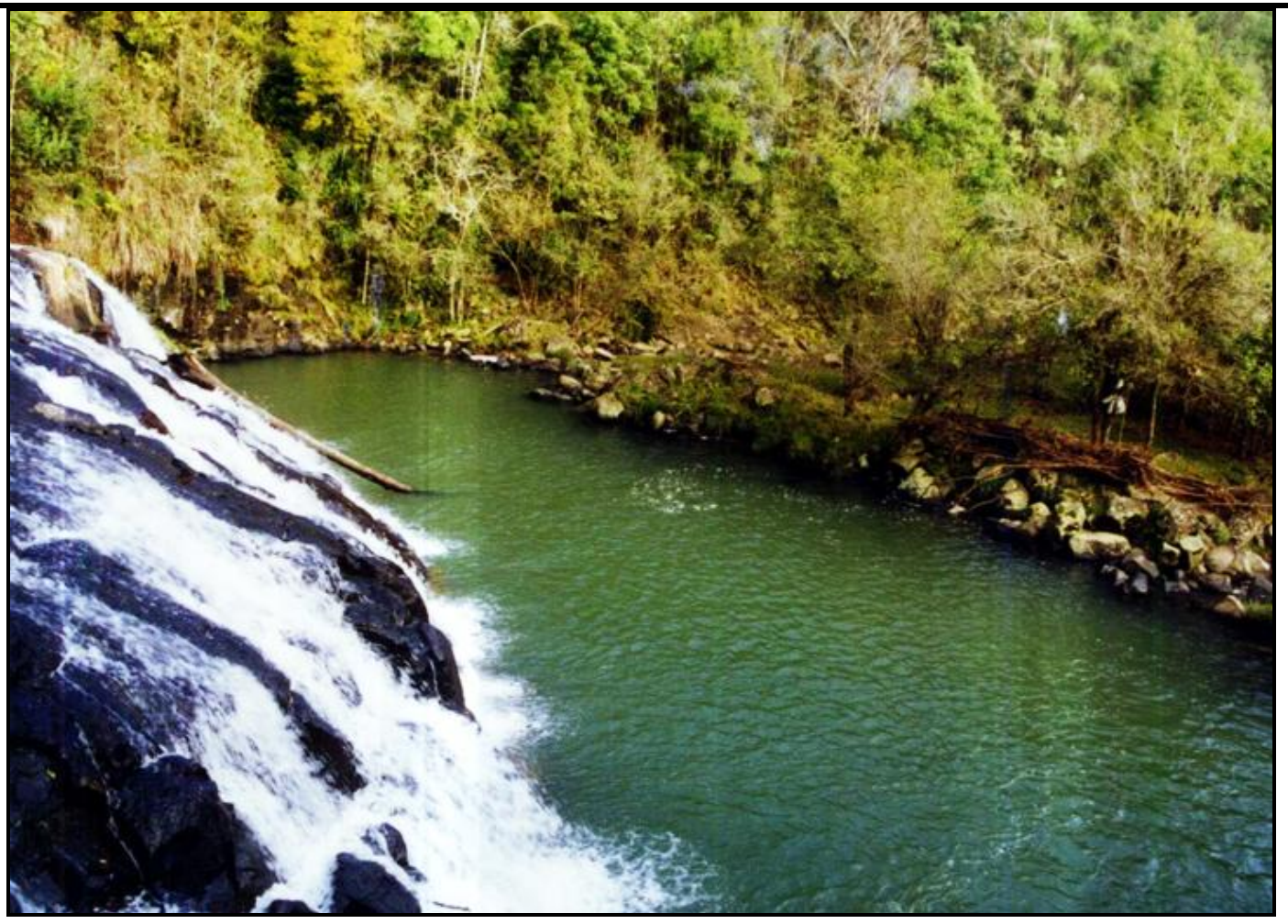

Figura 7: Cachoeira do Teodózio Hlatki

Fonte: PMI (2010)

\section{$\checkmark$ Caverna do Canhadão}

Essa caverna apesar de seu potencial turístico, não recebe muitas visitações. Segundo a PMI ela vem sendo visitada somente por escolas e pela Secretaria da Agricultura do Município. Ela está localizada em uma propriedade particular, a $30 \mathrm{~km}$ da sede municipal, sendo que se para chegar a esse ponto é necessário percorrer $1 \mathrm{~km}$ em meio à mata fechada. Possui 48 metros de largura por 52 metros de comprimento (figura 8).

\section{$\checkmark$ Arquiteturas Religiosas}

As arquiteturas religiosas são voltadas, quase que fundamentalmente, para as práticas sociais de cunho religioso. A importância que essas têm para o turismo precede mais pelo seu valor estético e sua fisionomia diferenciada. A PMI entende que essas edificações podem ser considerados atrativos do município.

Entre essas arquiteturas encontram-se: a Igreja Nossa Senhora da Luz (figura 9), a Igreja São Miguel (figura 10), a Igreja Imaculado Coração de Maria (figura 11), que se encontram no centro da cidade, e a Igreja Assunção de Nossa Senhora (Figura 12), localizada no Distrito de Itapará. 


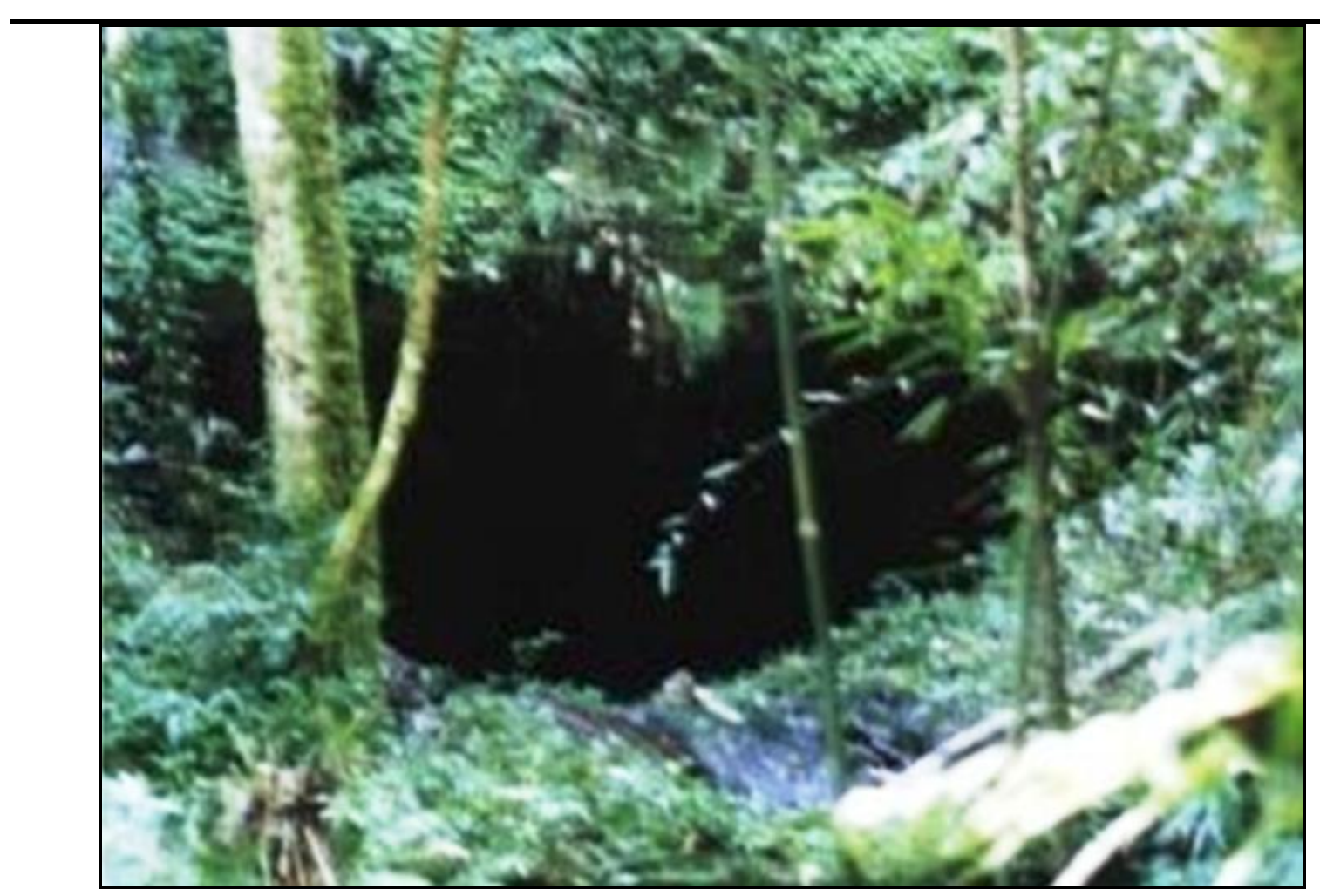

Figura 8: Caverna do Canhadão Fonte: PMI (2010).

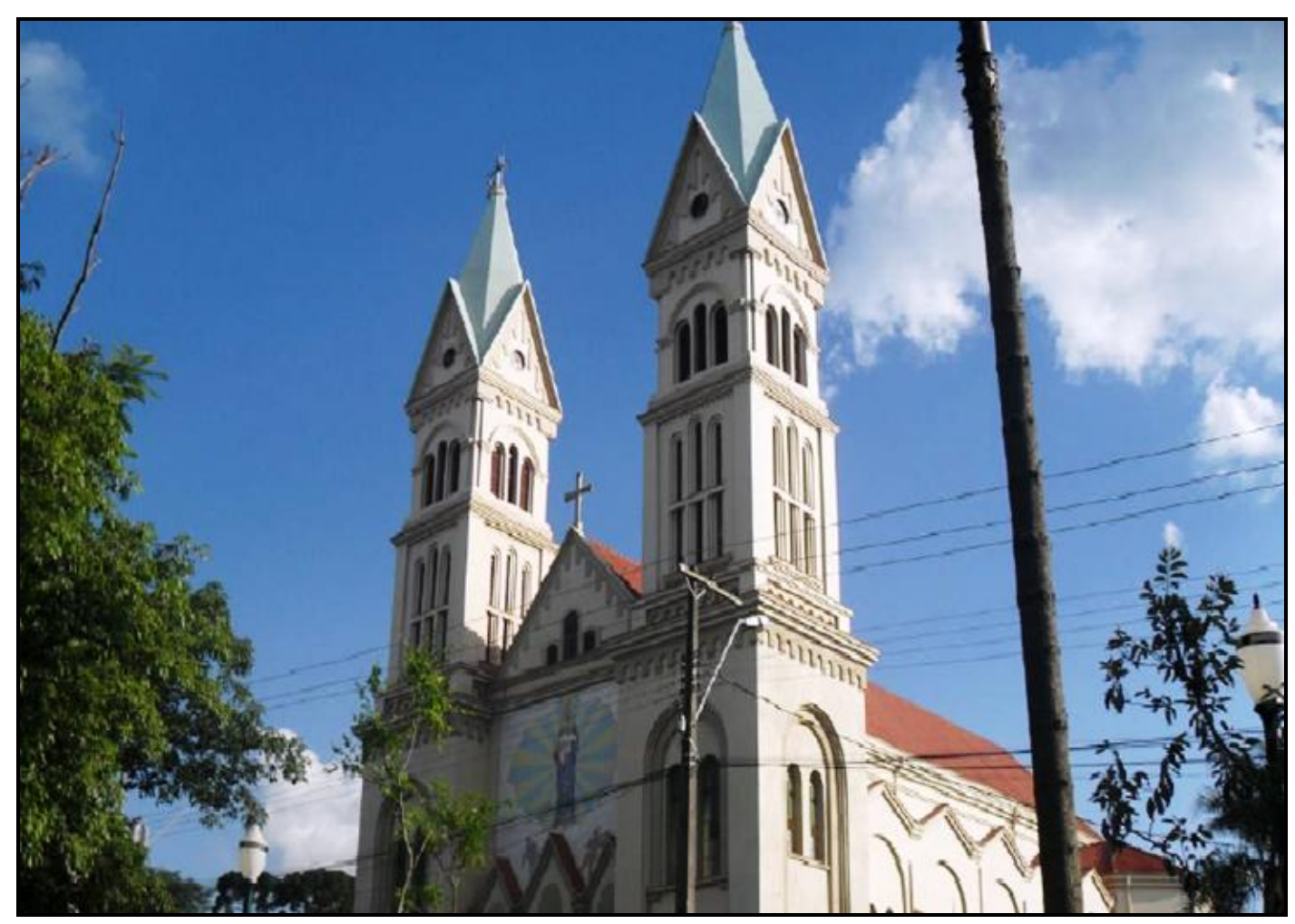

Figura 9: Igreja Nossa Senhora da Luz Fonte: TCHMOLO (2012) 


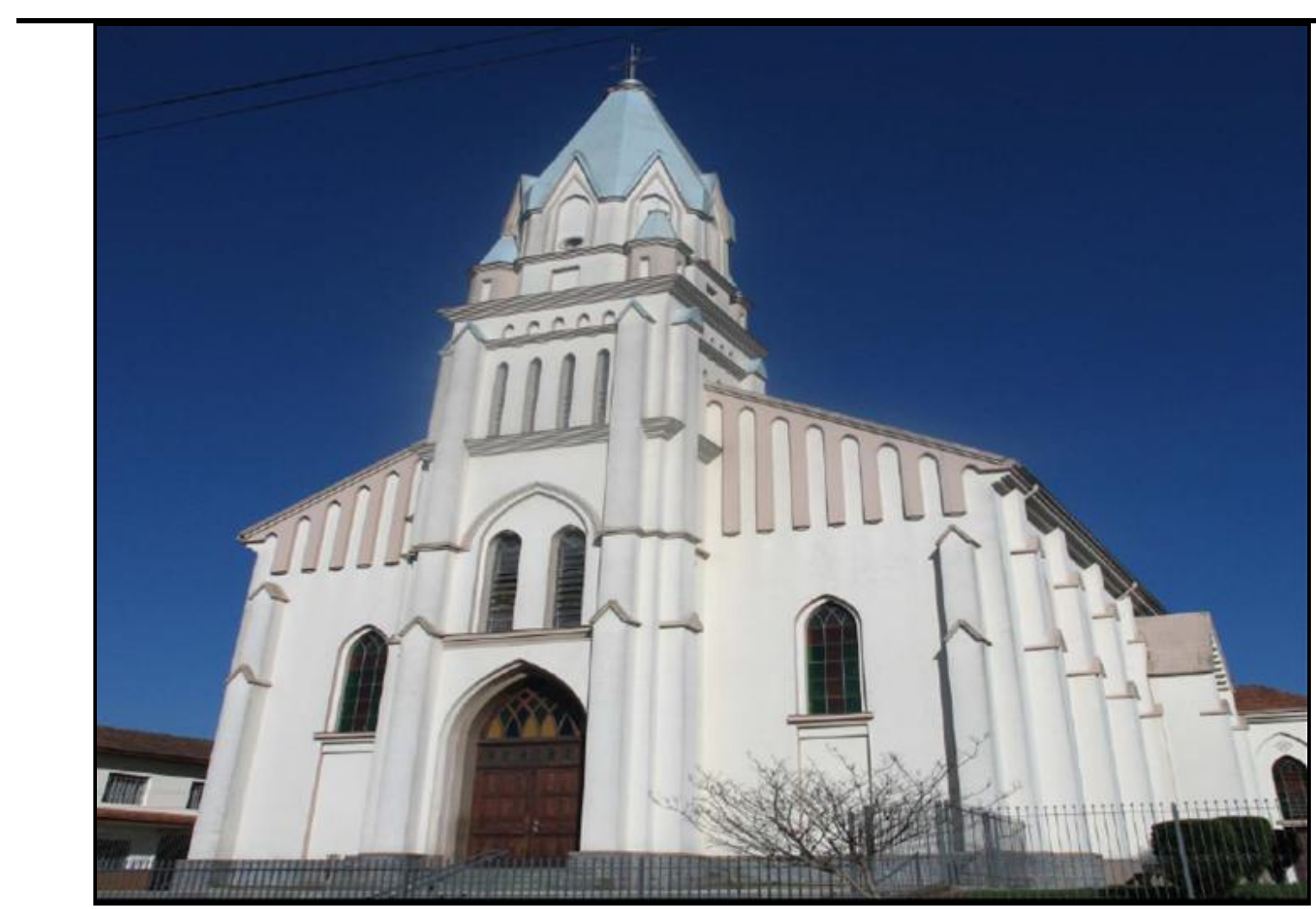

Figura 10: Igreja São Miguel

Fonte: PMI (2010)

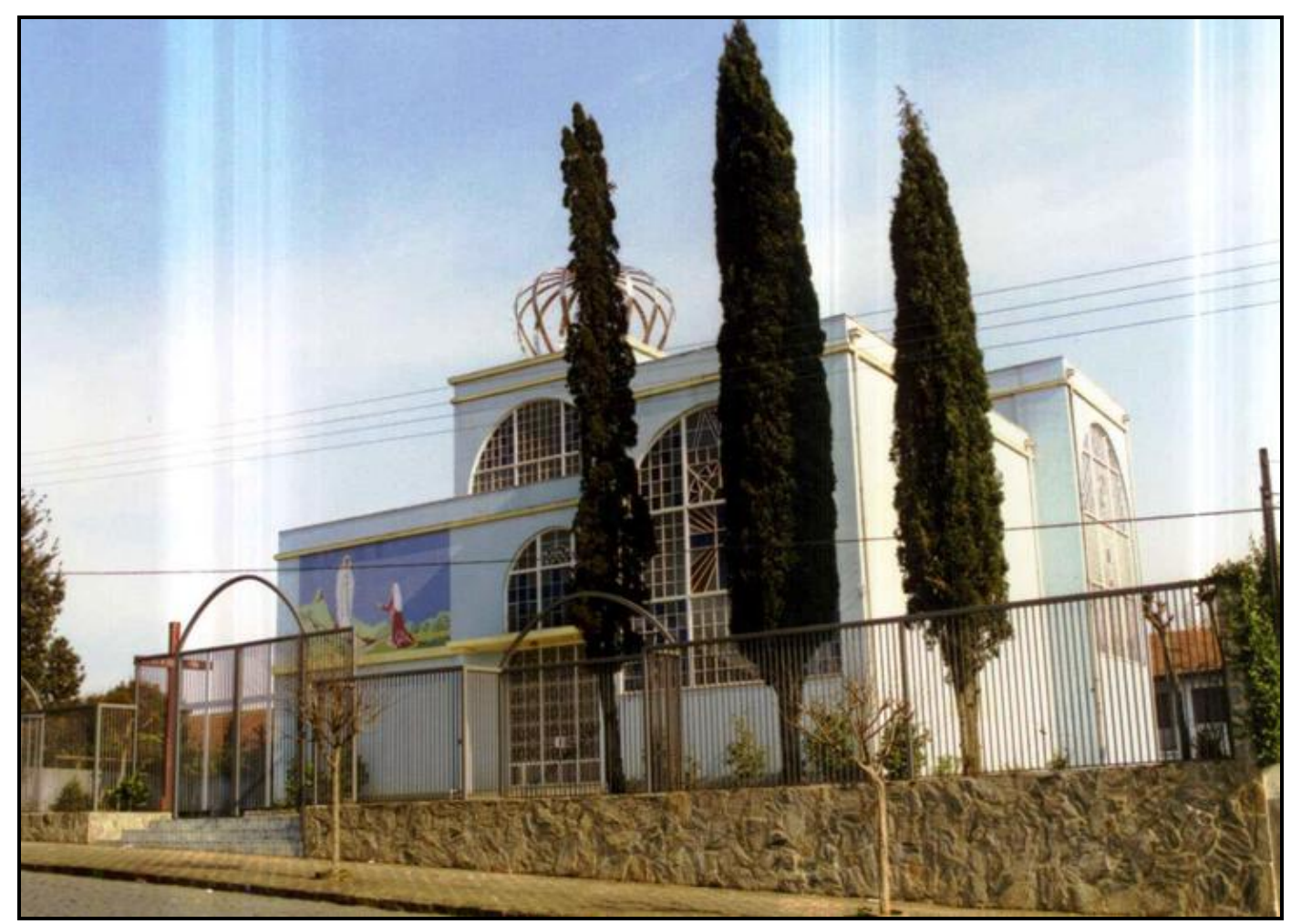

Figura 11: Igreja Imaculado Coração de Maria

Fonte: PMI (2010) 


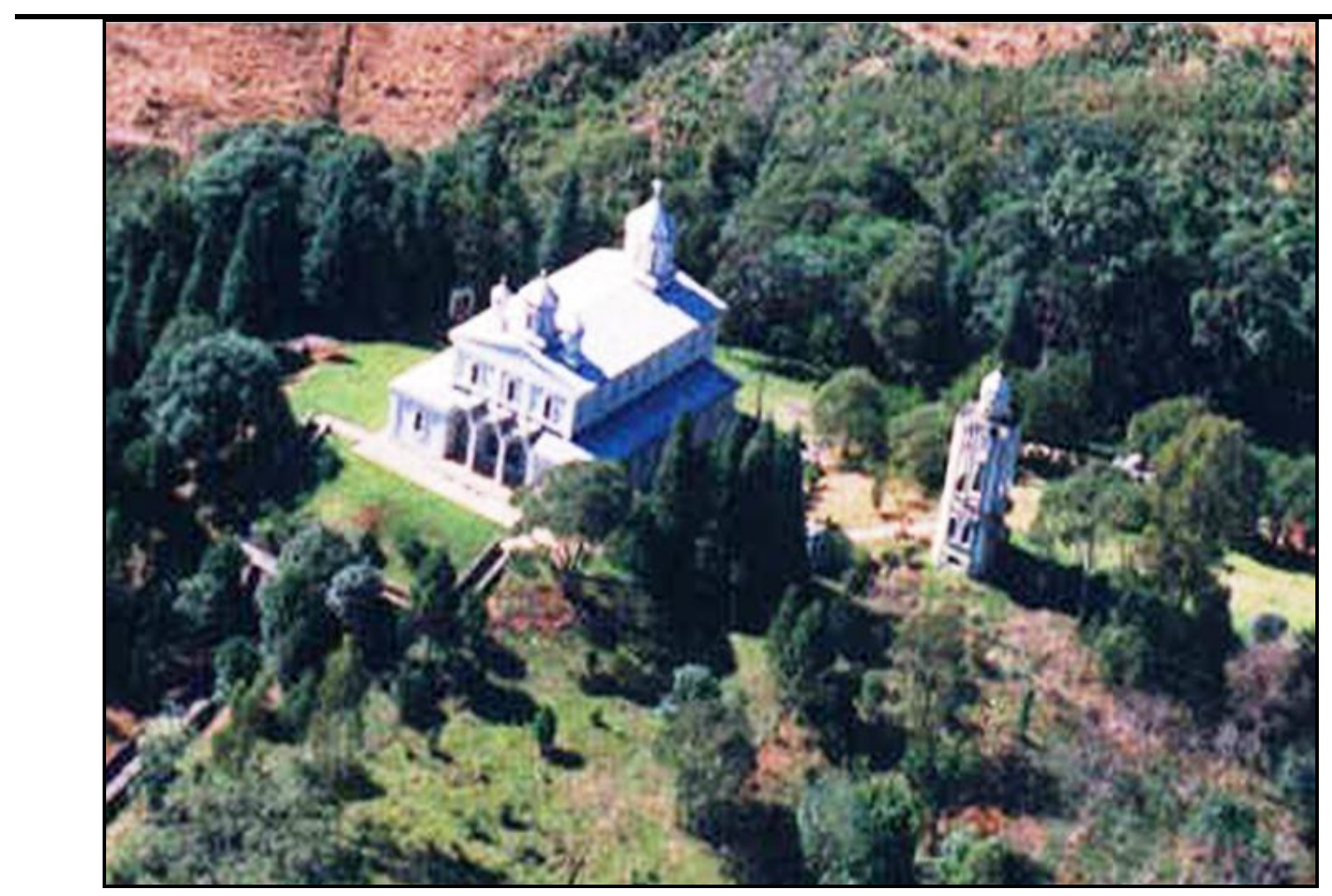

Figura 12: Igreja Assunção de Nossa Senhora (Itapará)

Fonte: PMI (2010)

\section{$\checkmark$ Casa da Cultura}

A Casa da Cultura (figura 13) é um antigo casarão que foi residência da família Gomes. Possui traços impostos pela cultura então vigente, sua construção data o ano de 1919. Esse local possui um acervo significativo da história do município transposta paras as mais variadas formas de expressão (PMI, 2010).

\section{$\checkmark$ Teatro Denise Stoklos}

O Teatro Denise Stokolos (figura 14) é um empreendimento ainda em fase de construção, que será um dos maiores do Estado, possuindo espaço para a acomodação de mais de 300 pessoas. É uma arquitetura contemporânea que está se tornando um atrativo turístico, mesmo antes do término de sua construção. Atualmente, ficou decidido, em reunião realizada com o Governo do Estado, que a Universidade Estadual do Centro-Oeste (Unicentro) ficará responsável pelo terreno e pelas atividades que ali serão desenvolvidas (UNICENTRO, 2012). 


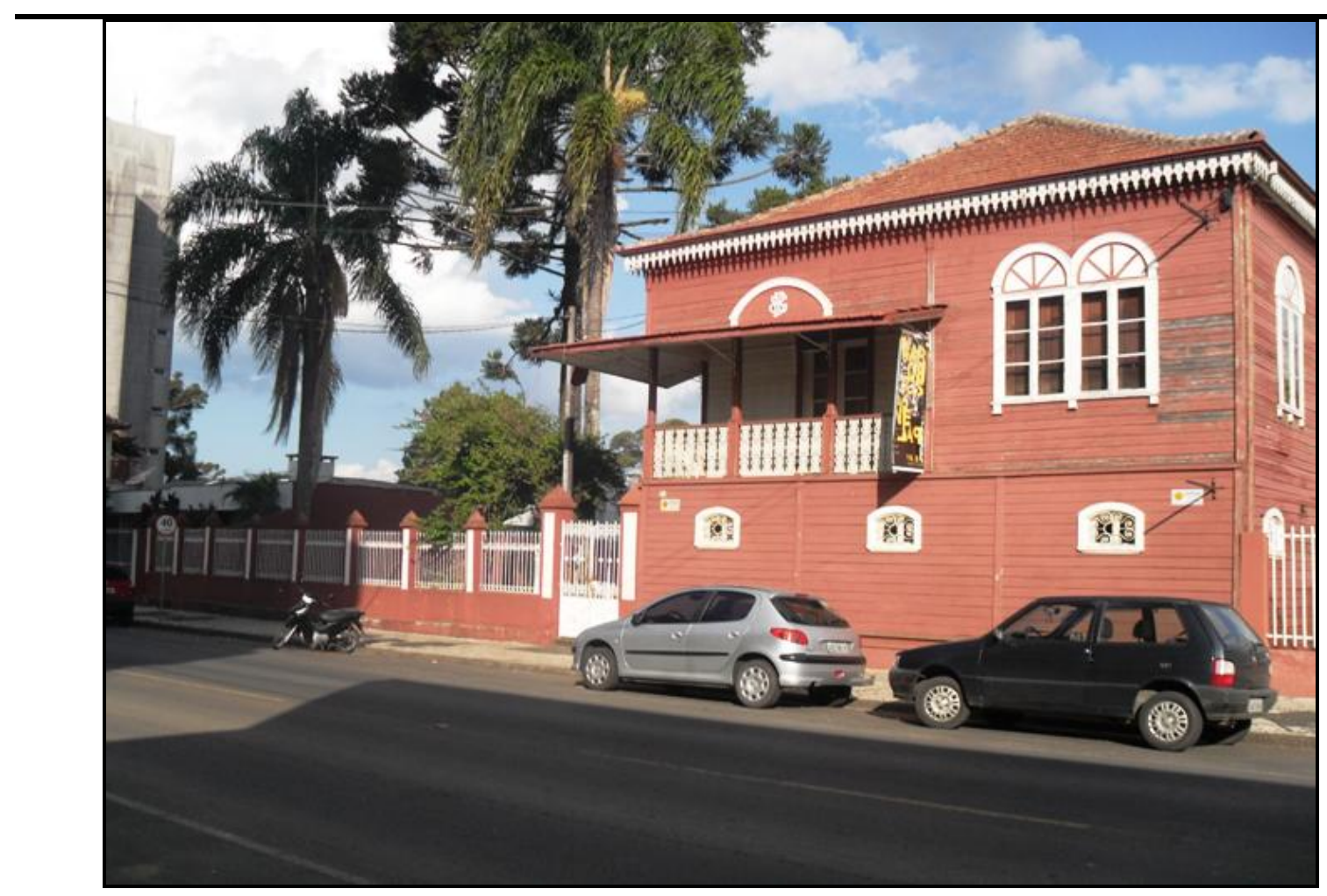

Figura 13: Casa da Cultura Fonte: TCHMOLO (2012).

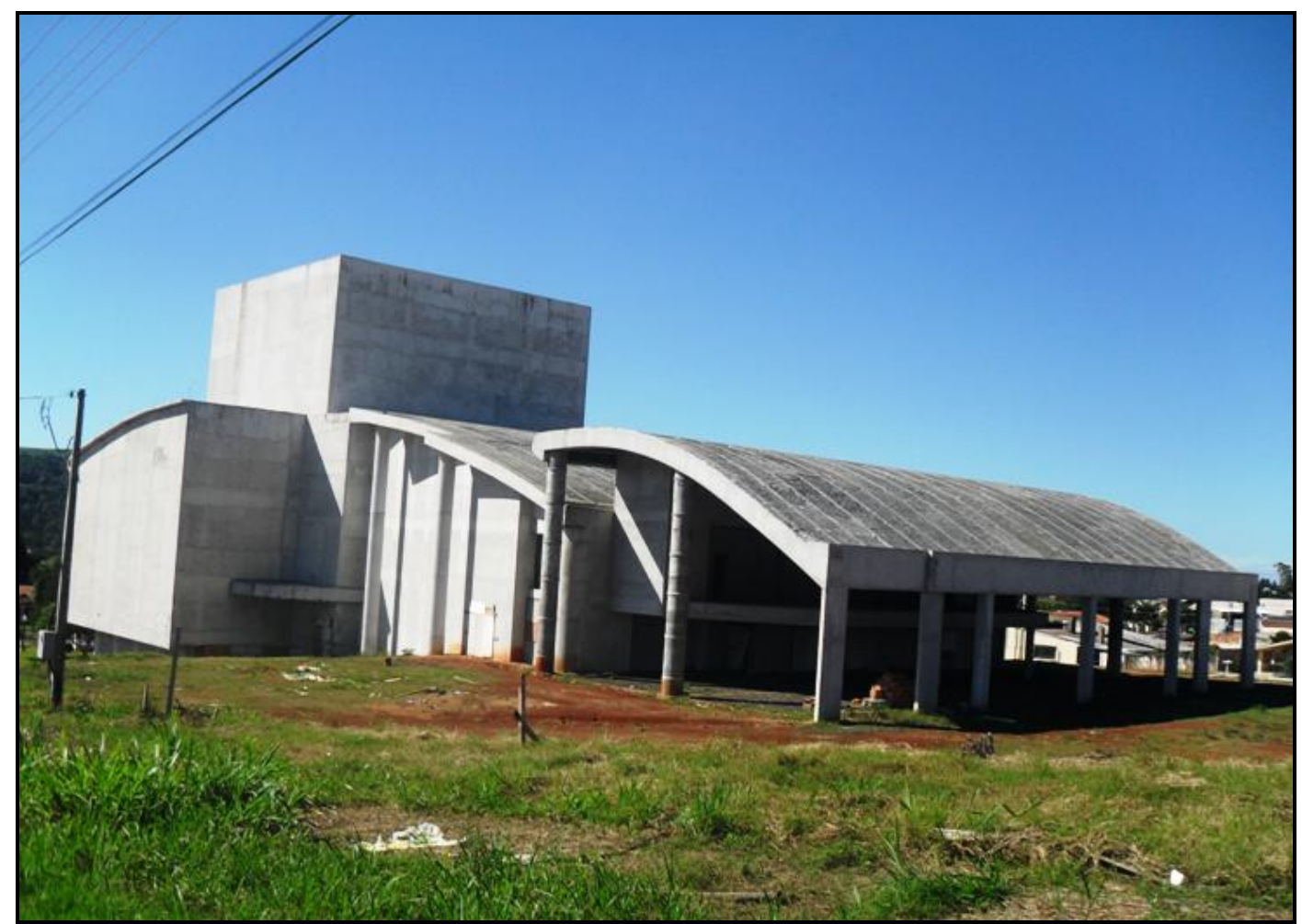

Figura 14: Teatro Denise Stoklos

Fonte: TCHMOLO (2012)

Esses são os atrativos, pontos ou paisagens turísticas de Irati. Percebe-se que há um emaranhado de segmentos turísticos que possuem potencialidade no município, como o 
turismo em áreas naturais, o turismo histórico, o turismo religioso, o turismo de lazer e entretenimento e o turismo cultural.

Contudo, como bem afirmado, são apenas atrativos catalogados pelo órgão municipal responsável, ainda não capazes de captar o turismo e, consequentemente, fazer com que essa atividade seja uma das principais fontes de renda do município. Logo, o que existe na localidade são as práticas sociais. Alguns exemplos podem ser percebidos através da vivência na cidade e por meio da observação assistemática. Por exemplo, a grande maioria da população idosa tem como exercício a ida semanal a uma Igreja e a clubes que promovem eventos para a terceira idade, isso não caracteriza que o Monumento Religioso seja um atrativo turístico para estes, mas um ambiente onde ele se relaciona espiritualmente ou socialmente.

Outro exemplo são as pessoas que se interessam pela prática de esporte. 0 deslocamento deste para o Parque Aquático não tem por objetivo a visita a um ponto turístico, mas a satisfação de realizar exercícios físicos. Eis que é uma prática social vivenciada por este indivíduo.

\section{Planejamento turístico em Irati-PR: transformações no espaço, na paisagem ou no}

\section{lugar?}

O lugar de vivência de um ser humano se sobressai a questões múltiplas de subjetividade, que, basicamente, originam-se de fatores psicológicos, sociais, políticos, religiosos ou econômicos. Viver em determinada cidade pode extrapolar os limites de satisfação e afeto por parte de um indivíduo por aquele lugar e/ou pelos elementos paisagísticos dispostos nele; ou, existe apenas uma necessidade da pessoa ali viver, pois a inópia trabalhista ou econômica o fez se deslocar para garantir sua sobrevivência e sua estabilidade financeira. Em suma, viver num lugar pode exceder o seu nível de satisfação ou não fazer diferença para uma pessoa.

Deste modo, o lugar exprime as tradições, os costumes, os modos de uso de uma coletividade (o subjetivo). O espaço se revela como um ambiente de produção, de mutações na sua forma e função (o objetivo), enquanto a paisagem se modifica no espaço devido às necessidades dos seres humanos em determinada época histórica (SANTOS, 1985).

Assim sendo, o espaço e a paisagem são planejáveis, pois estão acopladas a uma lógica capitalista de mudanças durante a história. O lugar não se pode planejar, pois o lugar é 
interiorizado no ser humano, é a relação subjetiva entre indivíduo e ambiente vivido. Acerca disso, Carlos (1996, p. 17) diz que

O lugar é à base da reprodução da vida e pode ser analisado pela tríade habitante - identidade - lugar. A cidade, por exemplo, produz-se e revelase no plano da vida e do indivíduo. Este plano é aquele do local. As relações que os indivíduos mantêm com os espaços habitados se exprimem todos os dias nos modos do uso, nas condições mais banais, no secundário, no acidental. É o espaço passível de ser sentido, pensado, apropriado e vivido através do corpo (grifo da autora).

As práticas sociais indicam paisagens e lugares vivenciados e carregados de valores que não podem ser planejados do ponto de vista de uma lógica racional, porque não tem uma finalidade objetiva, mas um desígnio subjetivo e tradicional, ou seja, não há como quantificar e prever as práticas do cotidiano que se materializam na paisagem vivida (marca). E tem na cultura local as matrizes que condicionam as práticas espaciais.

Afirma-se, deste modo, que a visão de um planejamento turístico municipal é a de mercantilizar paisagens e espaços para tal prática, entretanto, o mesmo não tem como modificar o simbolismo imposto por determinada coletividade sobre seu lugar e sobre suas paisagens vividas. O ponto fundamental é que o turismo usa as representações sociais (valores, hábitos e crenças) para alcançar o seu objetivo comercial e financeiro (FERRARA, 2002).

Por conseguinte, o objetivo comercial do turismo é que um lugar seja dotado de riquezas simbólicas e socioculturais que despertem o interesse, consequentemente, o deslocamento do turista para esse ambiente. Ao mesmo tempo, é importante que este contenha paisagens e espaços de circulação com o mínimo de infra-estrutura e que agradem aos olhos de quem por ali passa ou visita. Logo, esses aspectos tangíveis e intangíveis são recursos e produtos para o fomento do turismo.

A partir do entendimento que ainda é precário e quase nulo o planejamento do turismo em Irati, questionou-se ao Secretário Responsável, Sr. Rafael Ruteski, sobre sua sobre o planejamento do turismo na cidade. O mesmo contrapôs:

Eu percebo que nós temos que dar alguns passos nesse sentido. Eu acho que um planejamento estratégico, que já traçamos junto com a Samanta, é importante. Nós temos que pensar em ações a curto prazo que nós fazemos, mas porém, nós temos que estar atentos que uma qualidade nesse tipo de serviço só virá ao longo do tempo, porque nós precisamos, principalmente, de algumas questões que é: o retorno da sociedade para com o poder público, para com o turismo [...] (entrevista concedida em agosto de 2011) 
A Sra. Samanta Regina dos Santos, Chefe do Departamento de Turismo, quando indagada sobre a participação popular e empresarial expôs, quanto uma ação voltada para a composição de um Conselho de Turismo na cidade: "Foram três reuniões só para fazer a eleição, e todo mundo fugiu na hora, ninguém quer." Continuamente, citou o caso da realização de um Fórum de Turismo:

[...] o fórum a gente fez ofício, até junto com o vereador W. M., fomos em mãos convidar, entregar para o pessoas dos hotéis e tudo mais, ou nós saíamos levando 'corridão' do local, ou as pessoas nem compareceram. E é o que acontece com as reuniões também, a gente faz ofício, vai nos lugares longe, sem ter o carro do departamento, chega na hora, aparecem duas ou três pessoas. (entrevista concedida em agosto de 2011).

Esses pontos remetem à ausência de participação da iniciativa privada nas questões sobre o turismo na cidade, bem como a falta de organização perante a Prefeitura Municipal de Irati. Como disse o Secretário do Turismo em Irati, o planejamento estratégico para o turismo ainda é uma ideia, sendo que esta ainda não saiu do imaginário para o objetivo.

Contudo, crê-se, por um lado, que há necessidade de todos os envolvidos com o turismo para o nascimento e crescimento desta atividade. Assim, explorar a colaboração e a aceitação da sociedade, instigar o interesse da iniciativa privada e explorar os recursos e a aplicabilidade das ações do Estado é uma forma para se desenvolver o turismo como atividade social e econômica no município. Só que, por outro lado, existe a resistência por parte da iniciativa privada, a falta de organização pública, logo o não conhecimento da comunidade perante projetos para o desenvolvimento do turismo em Irati. Fica evidente que não existe planejamento turístico para Irati, do mesmo modo não há turismo.

Contudo, ainda existem possibilidades de mudança dessa situação; e é através da relação harmônica entre Estado, a iniciativa privada e os moradores, tendo em vista que todos sejam beneficiados nesse processo. E que a comunidade seja engajada para que perceba os resultados e, assim, contribua para o desenvolvimento bem proporcionado da atividade. Acerca disso, Cardozo (2007) enfatiza que "pensar o planejamento turístico municipal é pensar não apenas no destino propriamente dito, mas, sobretudo pensar no entorno e na comunidade que este abriga".

Uma ação apta e coerente a ser delegada em um município é o de planejamento participativo, pois este segundo Cesar (2005)

O relevante para o planejamento participativo é sem dúvida a busca pelo envolvimento da população engajar as pessoas em programas e projetos 
setoriais para que assim as pessoas entendam que o turismo gera não somente renda para os moradores do local como um prazer pessoal na realização de trabalhos como: artesanatos, culinárias, estudos históricos, enfim, proporciona prazer para só mesmo e para o próximo.

O planejamento turístico em uma municipalidade, portanto, deve analisar todo o contexto que se rodeia: a viabilidade econômica, a aceitação dos sujeitos que trabalham direta e indiretamente com o turismo, a acedência da população local, as precauções com o meio ambiente, etc.

O planejamento, também, varia entre aspectos que podem ser pensados na hora de traçar um projeto, um programa ou um plano. O porquê do planejar? Esse planejamento está sendo voltado para quem, com qual finalidade? Teoricamente, trabalhar o planejamento turístico municipal não remete a pensar somente no turista, somente naqueles que irão depositar capital no lugar, como salientado assim por Cadozo (2007), mas também nos residentes, pois, certamente estes, serão os principais responsáveis pela manutenção destas estratégias e ações do planejamento.

Para que se realize um planejamento turístico capaz de relacionar todos os sujeitos em Irati, há necessidade da formulação de um Plano de Desenvolvimento Turístico Municipal, onde contenham todas as informações inerentes sobre os benefícios e os empecilhos que serão encontradas para se fomentar o turismo. Logo, realizar um levantamento sobre essa possibilidade seria a melhor forma de agregar um conjunto único de interessados para a promoção turística. Todavia, lembrando sempre as precauções sociais e ambientais que o mesmo pode ocasionar.

Ainda na questão do planejamento, foi perguntado aos representantes do poder público, se existem projetos voltados para o turismo no município e qual a possibilidade destes atraírem turistas. Os mesmos responderam que existem as seguintes propostas: o projeto de Reestruturação do Planejamento Estratégico, o projeto de Turismo nas Escolas e o Programa Caldeirão Cultural.

Sobre o Projeto Turismo nas Escolas, a Sra. Samanta explicou que:

[...] o projeto tem uma forma onde a professora consegue utilizar o turismo tanto em Geografia, como em Matemática, Português, em tudo. Desde conhecendo a rua em que você mora, o bairro, a cidade, os pontos turísticos da cidade onde você mora, envolvendo crianças [...] Aí a gente tem visitas técnicas também, igual a gente fez uma viagem, por exemplo, para São Mateus na Petrobras, com as crianças, trabalhando o turismo ecológico, ecoturismo, a educação ambiental, mostrando que o turismo também tem a parte da recreação. Mas o que falta para esse projeto dar 
mais certo é a gente conseguir um ônibus só para esse projeto (entrevista concedida em agosto de 2011).

Acerca do Programa Caldeirão Cultural, o Sr. Rafael comentou que essa ação:

[...] é em virtude das grandes manifestações culturais, alguns até contestam, mas fazem isso porque não conhecem, mas é muito forte em Irati e muito organizadas. O Caldeirão Cultural contempla todas as características: teatro, música, artes visuais, são concursos musicais com pessoas de fora, re-estruturação da Casa da Cultura, festival de MPB, fortalecimento dos grupos folclóricos, [...] (entrevista concedida em agosto de 2011).

O destaque pelo turismo cultural e religioso foi bastante mencionado pelos responsáveis pelo turismo no município. Eles dizem que existem projetos voltados a visitação do ponto turístico principal da cidade (a Imagem de Nossa Senhora das Graças), bem como um roteiro que leva os visitantes a conhecer os monumentos religiosos de todo o município.

Em outra interrogativa, percebeu-se que há algumas ações que estão sendo voltadas para o turismo de Irati, com consciência e entendimento por parte dos responsáveis, contudo, sem uma organização e planejamento adequado, em conformidade com as necessidades primárias para o turismo:

[...] nós sabemos da necessidade de uma aproximação com a academia, com a universidade, com o curso de turismo e a ciência [...] todos os dados que nós temos, nós procuramos confrontar sempre com outras literaturas, com outras cidades semelhantes a nós, [...] Na questão de obras nós pontuamos alguns locais da cidade, por exemplo, na Santa e no Parque Aquático foram feitas reformas para melhoria do turismo [...] investimentos de projetos, também, no parque aquático da Vila São João e recuperação do Bosque São Francisco. E por fim, a liberação da cachoeira do Fillus para o poder público, nós já podemos explorar, mas precisamos que o terreno seja oficialmente do município, se não nós não podemos fazer o que queremos lá, nem estabelecer outras parcerias, então só falta o jurídico cuidar da parte legal. E é nessa tecla que a gente precisa bater, que nós precisamos constituir nosso conselho, para conseguir fortalecer e desenvolver o turismo de Irati, porque podem aparecer outros gestores que queiram cancelar nossos projetos, e se tivesse o conselho ele não deixaria que isso acontecesse. (entrevista concedida em agosto de 2011).

Entre muitos empecilhos encontrados, na tentativa de se desenvolver uma política de planejamento turístico para Irati, notam-se duas ocorrências que impedem a progressão dessa finalidade: a ausência de uma organização e preparo da gestão pública municipal; e a falta de pesquisas quanto àquelas paisagens que são, mormente, para práticas sociais cotidianas do morador iratiense. Neste segundo caso, pois: a Santa e o Parque Aquático (pontuados pelos responsáveis como pontos turísticos de Irati) não possuem atratividade 
para que sejam considerados atrativos para a prática da atividade turística, mas são espaços em que os moradores podem realizar suas práticas sociais.

A partir disso, procurou-se elucidar se esses projetos seriam, fundamentalmente, voltados para o turista ou se estes pensavam no bem estar da população local (pois esses seriam os principais usuários dos pontos turísticos de Irati), questionou-se: E esses projetos que acontecem: visam o turista, ou visam primeiro a população local para depois o turista? A Sra. Samanta respondeu:

Primeiramente, querendo ou não, a gente visa o bem estar da população, pois por ela estar bem que o turista vem, não adianta a gente querer chamar o turista e a população não estar satisfeita [...] nós estamos cientes de que, por exemplo, o projeto do Parque Aquático na Vila São João, ele sozinho não vai atrair turistas (entrevista concedida em agosto de 2011).

O Sr. Rafael complementou: "Mas principalmente, a comunidade vai ter a oportunidade de fazer o seu lazer, de ter momentos de ter o seu bem estar, de praticar atividade físicas, que a comunidade vai ter um ponto de encontro, vai valorizar a comunidade" (entrevista concedida em agosto de 2011).

Deste modo, entende-se que há possibilidade do turismo ainda surgir em Irati, contudo não se devem dar passos largos, mas estabelecer detalhadamente e minuciosamente as etapas, estratégias e ações para que isso aconteça. Identificar e minimizar os empecilhos que possam ocorrer e maximizar as possíveis melhorias são formas apropriadas de começar a se planejar. Pois, com base em Hall (2004, p. 29)

Embora o planejamento não seja uma panacéia para todos os males, quando totalmente voltado para processos ele pode minimizar impactos potencialmente negativos, maximizar retornos econômicos nos destinos e, dessa forma, estimular uma resposta mais positiva por parte da comunidade hospedeira em relação ao turismo no longo prazo.

Essa entrevista mostrou que não existe um planejamento turístico no município de Irati, concomitantemente, notou-se que as ações estabelecidas nos projetos e programas possuem, ao menos, um pensamento e respeito pela população local, contudo sem a participação desta. Embora, o turismo seja inexistente em Irati, mesmo com todo o esforço dos responsáveis por esse setor, os pontos turísticos da cidade não devem ser desleixados pela organização pública municipal, pois as práticas sociais são comumente vistas nesses lugares e é um exercício cotidiano da comunidade visitar e apreciar esses locais.

\section{CONSIDERAÇÕES FINAIS}


Notou-se, durante essa pesquisa, que existem ações que se são desenvolvidos pelo governo municipal, ora procurou-se elucidar se esses projetos seriam, fundamentalmente, voltados para o turista ou se estes pensavam no bem estar da população local (pois esses seriam os principais usuários dos pontos turísticos de Irati).

Embora o turismo não seja a atividade que mais movimenta a economia do município de Irati, existem dados que ele vem crescendo e se desenvolvendo, a partir de iniciativas privadas e do governo estadual e municipal. As ações governamentais e privadas concernem, essencialmente, nas exposições do turismo histórico e religioso, resgatando a cultura polonesa e ucraniana, bastante presente e visível no município através do artesanato e gastronomia.

Nesse sentindo, a importância que se dá à essa atividade não é a realmente percebida perante aquelas cidades que são denominadas como turísticas ou, então, aquelas que procuram de alguma forma divulgar seus atrativos em cenário nacional ou internacional, como é o caso do município limítrofe, Prudentópolis. Em Irati, o apelo turístico parte, sobretudo, da Imagem de Nossa Senhora das Graças, que é reconhecida por pessoas, do Brasil e de algumas partes do mundo, que são ligadas e interessadas pelo turismo históricocultural-religioso.

Em geral, o turismo em Irati é invisível, inexistente. De modo que é um município ainda procurando entender os benefícios desta atividade, contudo, sem muitas perspectivas de crescimento ou desenvolvimento econômico. Essa afirmação pode ser constatada na divisão político-administrativa do município, pois o Departamento de Turismo está inserido dentro da Secretaria de Patrimônio Histórico, Turismo, Cultura, Lazer e Desportos, o qual tem por finalidade o desenvolvimento de projetos e a divulgação e promoção turística do município. Além disso, o município ainda não possui uma política pública para o Turismo.

Há ainda, muito, o que se fazer para que o turismo seja tratado como uma atividade de proeminência dentro da economia local. Conquanto, crê-se que a primeira ação a ser procedida é o estabelecimento de uma secretaria para o turismo, pois, a partir disso surgem maiores responsabilidades para àqueles ocupantes dos cargos preestabelecidos para essa repartição, consequentemente, uma política do turismo mais organizada e devidamente planejada.

Percebendo essa realidade do município procurou-se, também, trabalhar com o conceito e as peculiaridades de práticas sociais, pois, nota-se que os moradores utilizam os espaços e 
paisagens, tratados como turísticos, para alguma finalidade. Isso ocorre, principalmente, nos finais de semana. Residentes e pessoas de cidades vizinhas de Irati, visitam, por exemplo, a Imagem de Nossa Senhora das Graças para fazerem suas orações e apreciarem a bela vista do centro da cidade ou, então, se deslocam até o Parque Aquático para levarem seus filhos para se divertirem nos espaços infantis, andar de trenzinho e pedalinho. Ainda ocorre nesse espaço, o exercício de práticas esportivas, sobretudo, no verão, onde existem atividades programadas para os moradores como, por exemplo, caminhadas em volta do lago e aeróbica.

No caso de Irati, a visão quanto ao planejamento existe por parte dos responsáveis pelo turismo municipal, mas ainda é inexistente tanto o turismo, como o planejamento turístico na localidade. Percebe-se, também, que há o interesse de operacionalizar prerrogativas para o desenvolvimento do turismo em Irati, porém esbarram em questões burocráticas, do mesmo modo, que a falta interesse da iniciativa privada para com essa atividade.

\section{REFERÊNCIAS BIBLIOGRÁFICAS}

BARRETTO, M. et al.. Turismo, políticas públicas e relações internacionais. Campinas: Papirus, 2003.

BENI, M. C. Análise estrutural do turismo. São Paulo: Ed. Senac, 1997.

BOITEUX, Bayard. Promoção, entretenimento e planejamento turístico . São Paulo: Aleph, 2002.

BOLSON, J. H. G. A importância da paisagem na atividade turística. Revista Turismo (online). São Paulo, 2004.2 Disponível em: <http://www.revistaturismo.com.br/artigos/paisagem.html> Acesso em: 30/05/2010.

BOULLÓN, R. C. Planejamento do espaço turístico. Bauru, SP: EDUSC, 2002.

CASTRO, L. L.C. O Projeto Expedições para o turismo e Ação em Santo Amaro do Maranhão - contribuições para a construção das Politicas Públicas Municipais de Turismo. São Luiz, 2004.

CARLOS, A. F. A. O Lugar no/do mundo. São Paulo: Hucitec, 1996.

CÓDIGO DE ÉTICA MUNIDAL PARA O TURISMO. Disponível em: <ethics.unwto.org/sites. d.Il/files/docpdf/brazil_0.pd> acesso em: 12 de fevereiro de 2012.

FERRARA, L. D. A. Olhar periférico: informação, linguagem, percepção ambiental. 2 ed. São Paulo: Editora da USP, 1999.

FRIDGEN, Joseph. Dimensions of tourism. Trad. da autora. Michigan: AHMA, 1990. 
GARCIA-MONTRONE, A. et al. (2004): Práticas sócias, o que são? São Carlos: PPGE/UFSCar (material produzido pelos docentes da disciplina Práticas Sociais e Processos Educativos do Programa de Pós-Graduação em Educação da Universidade Federal de São Carlos).

HALL, C. M. Planejamento turístico: politicas, processos e relacionamentos. Tradução de Edite Sciulli, São Paulo: Contexto, 2001.

LISBOA, S. S. A importância dos conceitos da Geografia para aprendizagem de conteúdos geográficos escolares. Revista Ponto de Vista, Viçosa-MG, v.4, p.23-35, 2004.

LLONA, M. et al.. La planificación estratégica del desarrollo local en Perú: análisis de casos. Lima: Escuela para el Desarrollo, 2003.

PERRET, Bernard. L'évaluation des politiques publiques. Paris. La Documentation Française, 2007.

RUSCHMANN, Doris Van de Meene. Turismo e planejamento sustentável: A proteção do meio ambiente. Campinas: Papirus, 1997.

RUSCHMANN, D.; WIDMER, G. Planejamento turístico. In: ANSARAH, M. Turismo: como aprender como ensinar. Vol. 2. São Paulo: Senac, 2000.

Espaço e método. São Paulo: Nobel, 1985.

TEIXEIRA, E. L. O papel das políticas públicas no desenvolvimento local e na transformação da realidade. Disponível em: <http://www.fit.br/home/link/texto/politicas_publicas.pdf> acesso em: 04 de maio de 2012.

YÁZIGI, E. A importância da paisagem. In: YÁZIGI, E. Turismo e paisagem. São Paulo: Contexto, 2002, p. 11-28.

Turismo: uma esperança condicional. 3. Ed. São Paulo: Global, 2003.

Artigo recebido em 16/07/2013.

Artigo aceito em 06/11/2013. 